\title{
Frequency and diversity of trypanosomes in sheep and goats from Mongo County in South Gabon, Central Africa
}

\author{
Gael Darren Maganga ${ }^{1,2}$ id, Larson Boundenga1(D), Emmanuella Jacqueline Ologui-Minkue-Edzo ${ }^{1}$, Linda Bohou Kombila ${ }^{1}$, \\ Telstar Ghestin Ndong Mebaley ${ }^{1}$, Brice Kumulunguii, ${ }^{1,2}$ and Jacques François Mavoungou ${ }^{3}$
}

1. Centre International de Recherches Médicales de Franceville, BP 769, Franceville, Gabon; 2. Département de Zootechnologie, Institut National Supérieur d'Agronomie et de Biotechnologies, BP 901, Franceville, Gabon;

3. Department of Zootechnology, Institut de Recherche Agronomique et Forestière (IRAF-CENAREST), BP: 13354, Libreville, Gabon.

Corresponding author: Gael Darren Maganga, e-mail: gael_maganga@yahoo.fr

Co-authors: LB: boundenga@gmail.com,EJO: eedzo@yahoo.com, LBK: bohoukombilalinda@gmail.com, TGNM: telstarlunique@gmail.com, BK: kumulungui@yahoo.fr, JFM: mavoungoujacques@yahoo.fr Received: 10-02-2020, Accepted: 19-10-2020, Published online: 24-11-2020

doi: www.doi.org/10.14202/vetworld.2020.2502-2507 How to cite this article: Maganga GD, Boundenga L, Ologui-Minkue-Edzo EJ, Bohou Kombila L, Ndong Mebaley TG, Kumulungui B, Mavoungou JF (2020) Frequency and diversity of trypanosomes in sheep and goats from Mongo County in South Gabon, Central Africa, Veterinary World, 13(11): $2502-2507$.

\begin{abstract}
Background and Aim: Trypanosomosis is a major impediment to livestock farming in sub-Saharan Africa. It is a vectorborne disease caused by several species of protozoan parasites, namely, trypanosomes. The present study aimed to identify the diversity of trypanosome species infecting sheep and goats from Mongo County and to determine the frequency of these parasites.

Materials and Methods: This study was conducted on 286 trypanotolerant goats and sheep from Mongo regions located in South Gabon, using polymerase chain reaction.

Results: Analyses showed that the overall occurrence of trypanosomosis in small ruminants was 13.6\% (39/286). Our results also showed that two factors, species and season, could affect the occurrence rate of Trypanosoma. A total of six Trypanosoma species were identified, two in sheep (Trypanosoma simiae and Trypanosoma theileri) and five in goats (Trypanosoma vivax, T. simiae, T. simiae Tsavo, Trypanosoma congolense, and Trypanosoma brucei), though Trypanosoma simiae was the most important species. Mixed infections were also found in goats (54.5\%) and sheep (3.57\%).
\end{abstract}

Conclusion: Our study demonstrated that small ruminants could represent a reservoir of biodiversity for Trypanosoma parasites.

Keywords: diversity, Gabon, goat, polymerase chain reaction, Sheep, Trypanosoma.

\section{Introduction}

In sub-Saharan Africa, the population of small ruminants is estimated at 120 million [1]. In 2009, the total number of sheep and goats in Gabon was estimated at 222,000 [2], with approximately 143,630 raised using extensive rearing. This breeding method, which is considered economical for the breeder, forces the animal to be exposed to various pathologies, including abortive diseases [3]. Many pathogens can be the cause of abortion in small ruminants, including viruses, bacteria, fungi, and parasites [4] such as Toxoplasma gondii, Neospora caninum, and Trypanosoma spp. [5].

Trypanosomiasis is a vector-borne disease caused by several species of protozoan parasites, called trypanosomes [6]. African animal trypanosomiasis (AAT), also known as Nagana, is a disease that

Copyright: Maganga, et al. Open Access. This article is distributed under the terms of the Creative Commons Attribution 4.0 International License (http://creativecommons.org/licenses/ by/4.0/), which permits unrestricted use, distribution, and reproduction in any medium, provided you give appropriate credit to the original author(s) and the source, provide a link to the Creative Commons license, and indicate if changes were made. The Creative Commons Public Domain Dedication waiver (http:// creativecommons.org/publicdomain/zero/1.0/) applies to the data made available in this article, unless otherwise stated. affects several mammal species, including 100 million small ruminants, with considerable annual losses of meat, estimated at about 5 billion US dollars [7,8]. It is mainly caused by the parasites Trypanosoma congolense and Trypanosoma vivax and to a lesser extent Trypanosoma brucei brucei [9]. In addition to the trypanosomes mentioned above, Trypanosoma simiae, T. simiae Tsavo, and Trypanosoma theileri have also been identified in mammals. The first two are rarely present in ruminants but are more recognized for their pathogenicity in domestic and wild pigs $[10,11]$. T. theileri is widely observed in domestic cattle [12] and wild buffalo [13]. In general, according to Mattioli et al. [14], wild animals are a reservoir of trypanosomes and their role in domestic animal trypanosomosis varies according to animal species, Glossina and the trypanosome involved. Many small ruminant herds are present in the villages of Mongo County, located in the province of Nyanga, in South Gabon. In the same region, the presence of trypanosomes has already been demonstrated in cattle herds of the SIAT ranch [15]. To date, no data on trypanosome infections are available on small ruminants in Gabon. Therefore, it is important to identify the diversity of trypanosome species infecting sheep and goats. 
The present study aimed to identify the diversity of trypanosome species infecting sheep and goats from Mongo County and to determine the frequency of these parasites.

\section{Materials and Methods}

\section{Ethical approval}

For this study, oral consent was obtained from all breeders of small ruminants for blood sampling. Animal handling and blood sampling by the CIRMF veterinarians complied with the criteria for animal well-being.

\section{Study area and samples collection}

The study was conducted from June 2014 to September 2014, during the dry season, and in March 2018, the rainy season, in Mongo County, located about $65 \mathrm{~km}$ from Tchibanga, capital of the Nyanga Province of Southwest Gabon [16]. This difference in sampling time between the rainy and dry seasons was due to the difficulty of access in this area during the rainy season.

Blood samples were collected from sheep and goats of nine villages, with at least 20 individuals per village. A total of 286 blood samples (146 sheep and 140 goats) were randomly collected. Five milliliters of whole blood were collected from the jugular vein of each animal, using a $0.8 \times 2.5 \mathrm{~mm}$ Precision Glide BD Vacutainer needle and placed in EDTA tubes. Samples were then stored at $-80^{\circ} \mathrm{C}$.

Parameters such as host species (goats/sheep), sex (male/female), age (young/adult), and sampling season were documented during the collection. All samples were collected during the dry and rainy seasons.

\section{DNA extraction and polymerase chain reaction (PCR)}

DNA was extracted from $200 \mu \mathrm{L}$ of whole blood on a BioRobot EZ1 Advanced XL automat (Qiagen, Germany), using the EZ1 Virus Mini Kit version 2.0 (Qiagen), according to the manufacturer's instructions. The DNA obtained was quantified on a Qubit (Thermo Fisher Scientific, France), using the Qubit Kit dsDNA HS Assay kit (Invitrogen, France).
The trypanosome search was done in two steps using the recombinant Taq DNA polymerase kit (Life Technologies, France). The first PCR used the primers IST1, to amplify partial region 18 S and IST2, to amplify regions 5.8S and 28S, of trypanosomes [11]. The amplification is carried out with a final volume of $25 \mu \mathrm{L}$, containing $5 \mu \mathrm{L}$ of DNA, $2.5 \mu \mathrm{L}$ of $10 \times \mathrm{PCR}, 2 \mu \mathrm{L}$ of dNTPs (10 mM each), $2 \mu \mathrm{L}$ of $\mathrm{MgCl}_{2}(50 \mu \mathrm{M}), 0.24 \mu \mathrm{L}$ of each primer $(10 \mu \mathrm{M}), 3 \mu \mathrm{L}$ of Taq polymerase, and $12.72 \mu \mathrm{L}$ of RNAse-free water (Invitrogen).

Amplification involved $7 \mathrm{~min}$ at $95^{\circ} \mathrm{C}$, followed by 35 cycles of $1 \mathrm{~min}$ at $94^{\circ} \mathrm{C}, 1 \mathrm{~min}$ at $56^{\circ} \mathrm{C}$, and 2 min at $72^{\circ} \mathrm{C}$, followed by a final elongation at $72^{\circ} \mathrm{C}$ for $10 \mathrm{~min}$.

The nested PCR used primers ITS3 and ITS4 [11]. The amplification was carried out with a final volume of $25 \mu \mathrm{L}$, containing $1 \mu \mathrm{L}$ of DNA from the first PCR, $2.5 \mu \mathrm{L}$ of $10 \times$ PCR, $2 \mu \mathrm{L}$ of dNTP $(10$ $\mathrm{mM}), 2 \mu \mathrm{L}$ of $\mathrm{MgCl}_{2}(50 \mathrm{mM}), 0.24 \mu \mathrm{L}$ of each primer at $10 \mu \mathrm{M}, 0.3 \mu \mathrm{L}$ of Taq polymerase, and $16.72 \mu \mathrm{L}$ of RNAse-free water (Invitrogen). The nested PCR products were then separated using $1.5 \%$ agarose gel electrophoresis.

\section{Statistical analyses}

Analyses were performed using $\mathrm{R}$ commander software. Pearson's Chi-square $\left(\chi^{2}\right)$ test was used to compare the proportions of animals infected by trypanosome species in each sex, age, species, and season (critical value $<0.05$ ).

\section{Results}

The overall frequency of trypanosome infection was $13.6 \%$ (39/286). Of the 146 sheep and 140 goats that were studied, $19.2 \%(28 / 146)$ of the sheep and $7.8 \%(11 / 140)$ of the goats were Trypanosoma positive (Table-1). The occurrence of trypanosome infection in males $(16.4 \%)$ was higher than in females $(12.5 \%)$. Adults had a lower prevalence $(12.9 \%)$ than young $(15 \%)$ (Table-1). However, these findings were more pronounced in sheep compared to goats (Table-2). Furthermore, no significant differences were observed between age $(\mathrm{p}=0.80)$ and $\operatorname{sex}(\mathrm{p}=0.58)$ classes $($ Table- 1$)$.

Table-1: Overall prevalence of trypanosome infection in small ruminants.

\begin{tabular}{|c|c|c|c|c|c|c|c|c|}
\hline \multirow[t]{2}{*}{ Variables } & \multirow[t]{2}{*}{ Total number } & \multirow[t]{2}{*}{ Number of positive } & \multirow[t]{2}{*}{ Prevalence (\%) } & \multirow[t]{2}{*}{ HP+ } & \multicolumn{4}{|c|}{ Comparison } \\
\hline & & & & & $\chi^{2}$ & p-value & df & $\mathbf{S +}$ \\
\hline \multicolumn{9}{|l|}{ Sex } \\
\hline Male & 79 & 13 & 16.46 & + & 0.31 & 0.58 & 1 & \\
\hline Female & 207 & 26 & 12.56 & & & & & \\
\hline \multicolumn{9}{|l|}{ Age } \\
\hline Young & 100 & 15 & 15 & + & 0.062 & 0.80 & 1 & \\
\hline Adult & 186 & 24 & 12.90 & & & & & \\
\hline \multicolumn{9}{|l|}{ Species } \\
\hline Sheep & 146 & 28 & 19.17 & + & 5.13 & 0.024 & 1 & + \\
\hline Goat & 140 & 11 & 8.57 & & & & & \\
\hline \multicolumn{9}{|l|}{ Season } \\
\hline Dry & 140 & 11 & 7.85 & & 5.13 & 0.023 & 1 & + \\
\hline Rainy & 146 & 28 & 19.18 & + & & & & \\
\hline
\end{tabular}

"Young" is $\leq 24$ months; "Adult" is $>24$ months. HP+=Higher prevalence between different parameters, $\mathrm{S}+=$ Test significant for the Chi-square test 
Molecular analyses revealed that a total of six trypanosome species were found in small ruminants, more specifically, five Trypanosoma species in goats (T. vivax, T. simiae, T. simiae Tsavo, T. congolense, and T. brucei) and two in sheep (T. simiae and T. theileri) (Figure-1). Infection rates of Trypanosoma species varied between hosts (Table-3), though only for two species showed a significant difference between goats and sheep. Indeed, T. simiae was more prevalent

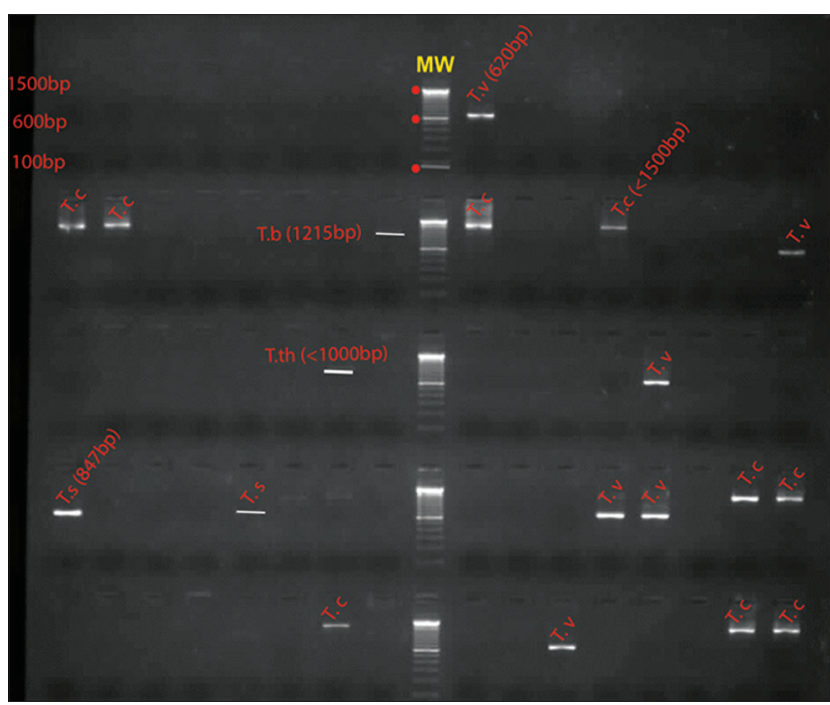

Figure-1: Gene amplification of trypanosomes using primers the ITS1, ITS2, ITS3, and ITS4 primers amplifying the $18 \mathrm{~S}$ partial region for ITS 1 and the $5.8 \mathrm{~S}$ and $28 \mathrm{~S}$ regions for ITS2. T.c=Trypanosoma congolense; T.b=Trypanosoma brucei; T.v=Trypanosoma vivax; T.s=Trypanosoma simiae; T.th=Trypanosoma theileri; MW=Molecular weight.

Table-2: Statistical analysis of Trypanosoma infection in sheep and goats of the Mongo County.

\begin{tabular}{|c|c|c|c|c|}
\hline \multirow[t]{3}{*}{ Variables } & \multicolumn{2}{|c|}{ Goats } & \multicolumn{2}{|c|}{ Sheep } \\
\hline & \multicolumn{2}{|c|}{$\chi^{2}$-test } & \multicolumn{2}{|c|}{$\chi^{2}$-test } \\
\hline & n/N (\%) & p-value & n/N (\%) & p-value \\
\hline \multicolumn{5}{|l|}{ Sex } \\
\hline Male & $2 / 277.41$ & 1 & $11 / 5221.15$ & 0.876 \\
\hline Female & $9 / 1137.96$ & & $17 / 9418.08$ & \\
\hline \multicolumn{5}{|l|}{ Age } \\
\hline Young & $3 / 427.14$ & 0.775 & $12 / 5820.68$ & 0.921 \\
\hline Adult & $8 / 988.16$ & & $16 / 8818.18$ & \\
\hline \multicolumn{5}{|l|}{ Season } \\
\hline Rainy & $2 / 603.33$ & 0.199 & $26 / 8630.23$ & $0.0013 *$ \\
\hline Dry & $9 / 8011.25$ & & $2 / 603.33$ & \\
\hline
\end{tabular}

$n$ denotes the number of positive individual and $\mathrm{N}$ is total number of the analyzed individual
$(18.49 \%)$ in sheep $(\mathrm{p}=0.0061 ; \mathrm{d} f=1)$, while $T$. simiae Tsavo was only found in goats with $5 \%$ of infection rate $(\mathrm{p}=0.022 ; \mathrm{d} f=1)$.

Among the infected individuals, the frequency of mixed infections observed in goats was 54.5\% (6/11), with various parasite associations. Only $3.57 \%(1 / 28)$ of sheep exhibited mixed infections (Table-4). The rates of coinfection in goats and sheep were statistically significant $(\mathrm{p}=0.013 ; \mathrm{d} f=1$; Chi-square $=6.14)$. The coinfection T. simiae-T. simiae Tsavo was predominant in goats.

Concerning the factors which could affect the infection level, the statistical analyses showed that two parameters could affect the infection rate: Species and season. Indeed, a significant difference was observed between the rainy and dry seasons $(\mathrm{p}=0.02$; $\mathrm{d} f=1$; Chisquare $=5.13$ ), with a higher infection level in the rainy season (Table-1). Table-2 shows that this difference was especially significant in sheep. The results also showed that the highest infection rate with trypanosome was recorded in sheep (18.4\%), which was significantly higher $(\mathrm{p}=0.024 ; \mathrm{d} f=1$; Chi-square $=5.13)$ than infection rate in goats $(8.5 \%)$ (Table- 1$)$.

\section{Discussion}

Trypanosomiasis in animals, particularly livestock, is a major impediment to livestock development in some rural areas of Africa affected by this disease. During these last few years, several studies reported many species circulating among farm animals [17-20]. Indeed, these studies about the disease burden of AAT in some livestock could invite a reevaluation of trypanosomiasis control strategy [21]. Few records exist on the effect of trypanosomosis in small ruminants in Africa, in particular Central Africa. Our study, which is the first in Gabon, assesses goat and sheep trypanosome infection prevalence and attempts to identify the diversity of species circulating in South Gabon.

In the present study, all identified species were already observed among small ruminants. Therefore, our study revealed that five Trypanosoma species infect goats ( $T$. vivax, $T$. simiae, T. simiae Tsavo, T. congolense, and T. brucei) and two sheep (T. simiae and $T$. theileri). Infection rate ranged from 0.71 to $5.71 \%$ in goats and 1.37 to $18.49 \%$ among sheep, thus, our study revealed a higher rate of trypanosome infection in sheep than goats. These results are consistent with the previous studies that have shown sheep

Table-3: Parasites diversity found in small ruminants.

\begin{tabular}{lccr}
\hline Trypanosoma species & Goats & Sheep & p-value $\chi^{2}$-test \\
\hline Trypanosoma vivax & $2.14 \%(3 / 140)$ & $0(0 / 146)$ & 0.24 \\
Trypanosoma simiae & $5.71 \%(8 / 140)$ & $18.49 \%(27 / 146)$ & $0.0061^{*}$ \\
Trypanosoma simiae Tsavo & $5.00 \%(7 / 140)$ & $0(0 / 146)$ & $0.022 *$ \\
Trypanosoma theileri & $0(0 / 146)$ & $1.37 \%(2 / 146)$ & 0.502 \\
Trypanosoma brucei & $0.71 \%(1 / 140)$ & $0(0 / 146)$ & 0.986 \\
Trypanosoma congolense & $0.71 \%(1 / 140)$ & $0(0 / 146)$ & 0.986 \\
\hline
\end{tabular}

This table reports the prevalence of each parasite identified and compares the prevalence between the goats and sheep. Statistical significance is indicated with an asterisk 
Table-4: Percentage of mixed infections detected in small ruminants.

\begin{tabular}{lcl}
\hline Host species & $\begin{array}{c}\text { Percentage of } \\
\text { mixed infections }\end{array}$ & Parasite associated $(\mathbf{n})$ \\
\hline Goats & $54.5 \%(6 / 11)$ & $\begin{array}{l}\text { Trypanosoma vivax-Trypanosoma simiae-Trypanosoma simiae Tsavo (1) } \\
\text { Trypanosoma vivax-Trypanosoma simiae (1) } \\
\text { Trypanosoma simae-Trypanosoma simiae Tsavo (4) }\end{array}$ \\
Sheep & $3.57 \%(1 / 28)$ & Trypanosoma simiae-Trypanosoma theileri $(1)$
\end{tabular}

$n=$ Number of mixed infection found

to be more frequently infected than goats $[21,22]$. This observation could be due the fact that goats are more refractory or resistant to trypanosome infections than sheep, as suggested by Ng'ayo et al. [21], which likely reflect the existence of some degree of trypanotolerance in goats [23]. Moreover, our results showed that sheep are more infected with $T$. simiae and $T$. theileri, while goats were only infected by three species (T. simiae, T. simiae Tsavo, and T. vivax). These observations contradict previous studies, which report that sheep are more infected with T. congolense and T. brucei than goats [24,25]. However, these two parasites were found only in goats but at a very low infection rate $(0.71 \%)$.

The species richness of trypanosomes was higher in goats than sheep, with five species identified in goats (T. vivax, $T$. simiae, $T$. simiae Tsavo, $T$. brucei, and $T$. congolense) and only two in sheep (T. simiae and $T$. theileri). Infection level varied according to the host species for each parasite found. We observed that in goats, T. simiae and T. simiae Tsavo were the parasites with the highest frequencies, at $5.71 \%$ and $5 \%$, respectively, and infection rate of $T$. vivax was $2.14 \%$. However, for sheep, only two parasites were found: $T$. simiae, at $18.49 \%$ (the highest infection rate in this study), and $T$. theileri (1.34\%). In Cameroon, $T$. simiae infection rate was $0.75 \%$ in goats and $0.37 \%$ in sheep [26]. The higher infection rate in small ruminants in Mongo County could be explained by the presence of various $T$. simiae reservoir animals. Indeed, this species, fatal in pigs, is predominant in wild pigs and can cause disease in small ruminants coexisting with wild pigs. T. simiae Tsavo, which causes mild disease in domestic pigs, has been found in warthogs [11].

$T$. vivax, T. brucei, and T. congolense were absent in sheep but present in goats with low infection rates. $T$. congolense and T. brucei, known to be important pathogens of cattle in Africa, were absent in sheep, as reported in the previous studies $[21,25,27]$. Our results support previous studies reporting the presence of these parasites in animals (dogs, cattle, and tsetse flies) at high prevalences [15,28-30].

Moreover, we observed mixed infections with two or three different Trypanosoma species, with the most common association being T. simiae and T. simiae Tsavo in goats. Our results support previous studies showing mixed infections of Trypanosoma species in livestock and the tsetse flies vectors of these parasites [21,31-33]. The mixed infections we observed in small ruminants could be explained by overexposure of animals to infected tsetse flies [31]. Thus, the presence of some Trypanosoma species could negatively impact human and animal health. Indeed, the presence of Trypanosoma species could affect the growth of farm animals [21]. Furthermore, a recent study reported cases of atypical human infections caused by animal trypanosomes species [34], including $T$. congolense, T. brucei, and T. vivax $[34,35]$, that we found in this study. Thus, sheep and goats that are infected with a wide variety of trypanosomes could constitute a reservoir for these parasites, and the permanent contact of animals with humans could promote the crossing of the host barrier and lead to human infection with trypanosomes normally found in animals.

Finally, we also showed that host species and season influence trypanosome infection in small ruminants. Indeed, we observed that sheep were significantly more infected than the goats $(\mathrm{p}=0.028)$. Although sheep and goats are well known to be trypanotolerant [36], it has been shown that there is a difference in the infection rate between these two animal species for some pathogens $[21,37,38]$. Regarding season, we showed that trypanosome infection in small ruminants was higher in the rainy season, corroborating previous study [39] and possibly explained by an observed increase vector abundance during the rainy season [39,40]. Differences between age and sex classes did not reach statistical significance, though the higher prevalence we observed in females and young agrees with the previous studies [39]. Thus, we conclude that the factors we investigated likely have an influence on infection of small ruminants by trypanosomes.

\section{Conclusion}

This study showed that small ruminants are reservoir animals of African trypanosomes. Small ruminants should be considered in trypanosomosis prophylaxis programs to prevent the spread of the disease. The study also suggests that wild animals could play a role in the spread of the disease in livestock. A study could also be undertaken to evaluate the impact of the disease on the productivity of these animals. However, further studies would be necessary to better characterize this Trypanosoma diversity, assess the risk to animal and human health, and understand the ecology of these parasites in Gabon.

\section{Authors' Contributions}

GDM conceived and designed the research. EJO and GDM conducted the sample collection. EJO, 
LBK, and TGNM carried out the molecular analysis. LB and EJO carried out the data analysis. GDM and LB wrote the manuscript. BK and JFM reviewed the manuscript. All authors read and approved the final manuscript.

\section{Acknowledgments}

The authors thank SIAT-Gabon for technical support and field assistance. We acknowledge especially Blaise Leko for field assistance and Joshua Bauld for the English editing. The CIRMF was supported by the Government of Gabon, Total-Fina-Elf Gabon, and the Ministère de la Coopération Française.

\section{Competing Interests} interests.

The authors declare that they have no competing

\section{Publisher's Note}

Veterinary World remains neutral with regard to jurisdictional claims in published institutional affiliation.

\section{References}

1. Tamini, L., Fadiga, M. and Sorgho, Z. (2014) Chaines de Valeur des Petits Ruminants au Burkina Faso: Analyse de Situation. ILRI, Nairobi, Kenya.

2. Akakpo, A., Têko-Agbo, A. and Koné, P. (2009) L'impact de la brucellose sur l'économie et la santé publique en Afrique. Conf. OIE, 2009: 71-84.

3. Lesnoff, M., Lancelot, R., Tillard, E. and Faye, B. (2001) Analyse comparative de la productivité des cheptels de petits ruminants en élevage extensif tropical: Une nouvelle approche par les modèles matriciels en temps discret. Rev. Elev. Med. Vet. Pays Trop., 54(1): 69-80.

4. Borel, N., Frey, C.F., Gottstein, B., Hilbe, M., Pospischil, A., Franzoso, F.D. and Waldvogel, A. (2014) Laboratory diagnosis of ruminant abortion in Europe. Vet. J., 200(2): 218-229.

5. Rekiki, A. and Rodolakis, A. (2004) Diagnostic Des Avortements Chez Les Petits Ruminants. Point Vétérinaire, ResearchGate, Berlin, Germany. p24-31.

6. Mwamba, W.K. and Malekani, J. (2017) Epidémiologie de la trypanosomose animale africaine (TAA) à l'ouest de la republique democratique du congo (RDC). Rev. Mar. Sci. Agron. Vét., 5(2): 108-111.

7. Mortelmans, J. (1986) Quelques aspects économiques en rapport avec la parasitologie vétérinaire. Tropicultura, 4(3): 112-116.

8. Geerts, S., Holmes, P.H., Eisler, M.C. and Diall, O. (2001) African bovine trypanosomiasis: The problem of drug resistance. Trends Parasitol., 17(1): 25-28.

9. Desquesnes, M. and Davila, A. (2002) Applications of PCR-based tools for detection and identification of animal trypanosomes: A review and perspectives. Vet. Parasitol., 109(3-4): 213-231.

10. Jahnké, H., Tacher, G., Keil, P. and Rojat, D. (1987) Production animale dans les régions d'Afrique infestée par les glossines in production animale en Afrique tropicale, plus particulièrement dans la zone infestée par les glossines. CIPEA-ILRAD. Compte Rendu Réunion, 1: 23-27.

11. Auty, H., Anderson, N.E., Picozzi, K., Lembo, T., Mubanga, J., Hoare, R., Fyumagwa, R.D., Mable, B., Hamill, L. and Cleaveland, S. (2012) Trypanosome diversity in wildlife species from the Serengeti and Luangwa Valley ecosystems. PLoS Negl. Trop. Dis., 6(10): e1828.

12. Villa, A., Gutierrez, C., Gracia, E., Moreno, B., Chacón, G.,
Sanz, P.V., Büscher, P. and Touratier, L. (2008) Presence of Trypanosoma theileri in Spanish cattle. Ann. N. Y. Acad. Sci., 1149(1): 352-354.

13. Desquesnes, M. (1999) Origin and distribution of new world livestock trypanosomes and their affinity for some mammalian hosts. Proc. First Symp. New World Tryp., 1: 5-11.

14. Mattioli, R., Jean, O. and Belem, A. (1990) Incidence of trypanosomiasis on wildlife of a game ranch in Burkina Faso. Rev. Elev. Med. Vet. Pays Trop., 43(4): 459-465.

15. Maganga, G.D., Mavoungou, J.F., N'Dilimabaka, N., Kinga, I.C.M., Mve-Ondo, B., Mombo, I.M., Ngoubangoye, B., Cossic, B., Okouyi, C.S.M., Souza, A., Leroy, E.M., Kumulungui, B. and Ollomo, B. (2017) Molecular identification of trypanosome species in trypanotolerant cattle from the South of Gabon. Parasite, 24(4): 4.

16. Maganga, G.D., Ndong, A.L.A., Okouyi, C.S.M., Mandanda, S.M., N'Dilimabaka, N., Pinto, A., Agossou, E., Cossic, B., Akue, J.P. and Leroy, E.M. (2017) Serological evidence for the circulation of rift valley fever virus in domestic small ruminants in Southern Gabon. Vector Borne Zoonotic Dis., 17(6): 443-446.

17. Ebhodaghe, F., Ohiolei, J.A. and Isaac, C. (2018) A systematic review and meta-analysis of small ruminant and porcine trypanosomiasis prevalence in Sub-Saharan Africa (1986 to 2018). Acta Trop., 188: 118-131.

18. Muhanguzi, D., Picozzi, K., Hattendorf, J., Thrusfield, M., Kabasa, J.D., Waiswa, C. and Welburn, S.C. (2014) The burden and spatial distribution of bovine African trypanosomes in smallholder crop-livestock production systems in Tororo district, South-Eastern Uganda. Parasit. Vectors, 7(1): 603.

19. Weny, G., Okwee-Acai, J., Okech, S.G., Tumwine, G., Ndyanabo, S., Abigaba, S. and Goldberg, T.L. (2017) Prevalence and risk factors associated with hemoparasites in cattle and goats at the edge of Kibale national park, Western Uganda. J. Parasitol., 103(1): 69-74.

20. Kelly, S., Ivens, A., Mott, G.A., O'Neill, E., Emms, D., Macleod, O., Voorheis, P., Tyler, K., Clark, M., Matthews, J., Matthews, K. and Carrington, M. (2017) An alternative strategy for trypanosome survival in the mammalian bloodstream revealed through genome and transcriptome analysis of the ubiquitous bovine parasite Trypanosoma (Megatrypanum) theileri. Genome Biol. Evol., 9(8): 2093-2109.

21. Ng'ayo, M.O., Njiru, Z.K., Kenya, E.U., Muluvi, G.M., Osir, E.O. and Masiga, DK. (2005) Detection of trypanosomes in small ruminants and pigs in Western Kenya: Important reservoirs in the epidemiology of sleeping sickness? Kinetoplastid Biol. Dis., 4(1): 5.

22. Snow, W.F., Wacher, T.J. and Rawlings, P. (1996) Observations on the prevalence of trypanosomosis in small ruminants, equines and cattle, in relation to tsetse challenge, in the Gambia. Vet. Parasitol., 66(1-2): 1-11.

23. Sinshaw, A., Abebe, G., Desquesnes, M. and Yoni, W. (2006) Biting flies and Trypanosoma vivax infection in three highland districts bordering lake Tana, Ethiopia. Vet. Parasitol., 142(1-2): 35-46.

24. Van den Bossche, P. (2001) Some general aspects of the distribution and epidemiology of bovine trypanosomosis in Southern Africa. Int. J. Parasitol., 31(5-6): 592-598.

25. Thonnus, M., Guerin, A. and Riviere, L. (2017) A multigene family encoding surface glycoproteins in Trypanosoma congolense. Microb. Cell., 4(3): 90-97.

26. Nimpaye, H., Njiokou, F., Njine, T., Njitchouang, G., Cuny, G., Herder, S., Asonganyi, T. and Simo, G. (2011) Trypanosoma vivax, Trypanosoma congolense forest type and Trypanosoma simiae: Prevalence in domestic animals of sleeping sickness foci of Cameroon. Parasite, 18(2): 171-179.

27. Franco, J.R., Simarro, P.P., Diarra, A. and Jannin, J.G. (2014) Epidemiology of human African trypanosomiasis. Clin. Epidemiol., 6: 257-275. 
28. Leak, S.G., Colardelle, C., D'Ieteren, G., Dumont, P., Feron, A., Jeannin, P., Minengu, M., Mulungu, M., Ngamuna, S. and Ordner, G. (1991) Glossina fusca group tsetse as vectors of cattle trypanosomiasis in Gabon and Zaire. Med. Vet. Entomol., 5(1): 111-120.

29. Watier-Grillot, S., Herder, S., Marié, J., Bourry, O., Cuny, G. and Davoust, B. (2016) Survey on Trypanosoma spp. Infection of dogs in Gabon and its epidemiological implications for sleeping sickness. Med. Sante Trop., 26(2): 221-223.

30. Tongue, L.K., Kamkuimo, R.G., M'eyi, P.M., Kaba, D., Louis, F.J. and Mimpfoundi, R. (2011) Entomological survey in the historical focus of human African trypanosomiasis of Bendje (Gabon). Parasite, 18(4): 303-309.

31. Nakayima, J., Nakao, R., Alhassan, A., Mahama, C., Afakye, K. and Sugimoto, C. (2012) Molecular epidemiological studies on animal trypanosomiases in Ghana. Parasit. Vectors, 5(1): 1-7.

32. Malele, I.I., Magwisha, H.B., Nyingilili, H.S., Mamiro, K.A., Rukambile, E.J., Daffa, J.W., Lyaruu, E.A., Kapange, L.A., Kasilagila, G.K., Lwitiko, N.K., Msami, H.M. and Kimbita, E.N. (2011) Multiple Trypanosoma infections are common amongst Glossina species in the new farming areas of Rufiji district, Tanzania. Parasit. Vectors, 4(1): 217.

33. Katunguka-Rwakishaya, E. (1996) The prevalence of trypanosomosis in small ruminants and pigs in a sleeping sickness endemic area of Buikwe county, Mukono district, Uganda. Rev. Elev. Med. Vet. Pays. Trop., 49(1): 56-58.

34. Truc, P., Buscher, P., Cuny, G., Gonzatti, M.I., Jannin, J., Joshi, P., Juyal, P., Lun, Z.R., Mattioli, R., Pays, E.,
Simarro, P.P., Teixeira, M.M.G., Touratier, L., Vincendeau, P. and Desquesnes, M. (2013) Atypical human infections by animal trypanosomes. PLoS Negl. Trop. Dis., 7(9): e2256.

35. Truc, P., Jamonneau, V., N'Guessan, P., N'Dri, L., Diallo, P.B. and Cuny, G. (1998) Trypanosoma brucei ssp. and $T$ congolense: Mixed human infection in Cote d'Ivoire. Trans. R. Soc. Trop. Med. Hyg., 92(5): 537-538.

36. Chiejina, S.N. and Behnke, J.M. (2011) The unique resistance and resilience of the Nigerian West African Dwarf goat to gastrointestinal nematode infections. Parasit. Vectors. 4(1): 12.

37. Goossens, B., Osaer, S., Kora, S., Chandler, K.J., Petrie, L., Thevasagayam, J.A., Woolhouse, T. and Anderson, J. (1998) Abattoir survey of sheep and goats in the Gambia. Vet. Rec., 142(11): 277-281.

38. N’Djetchi, M.K., Ilboudo, H., Koffi, M., Kabore, J., Kabore, J.W., Kaba, D., Courtin, F., Coulibaly, B., Fauret, P., Kouakou, L., Ravel, S., Deborggraeve, S., Solano, P., De Meeûs, T., Bucheton, B. and Jamonneau, V. (2017) The study of trypanosome species circulating in domestic animals in two human African trypanosomiasis foci of Cote d'Ivoire identifies pigs and cattle as potential reservoirs of Trypanosoma brucei gambiense. PLoS Negl. Trop. Dis., 11(10): e0005993.

39. Ohaeri, C. (2010) Prevalence of trypanosomiasis in ruminants in parts of Abia State, Nigeria. J. Anim. Vet. Adv., 9(18): 2422-2426.

40. Shields, V.D. (2017) Herbivores. IntechOpen, BoD-Books on Demand, Germany. p167. 